\title{
ВЪЗМОЖНОСТИ ЗА ПРИЛАГАНЕ НА ИНФОРМАЦИОННИТЕ СИСТЕМИ В СФЕРАТА НА ЗДРАВНИТЕ ГРИЖИ
}

\author{
Д. Иванова
}

\section{POSSIBILITY OF IMPLEMENTING INFORMATION SYSTEM IN THE AREA OF HEALTH CARE}

D. Ivanova

Рез юме. Създаването на организация на здравните грижи в болничните структури, която да отговаря на съвременните изисквания е невъзможно без въвеждането на информационни системи в работата на сестринския персонал. Основните професионални дейности на медицинките сестри са насочени към грижите за пациента и извършване на назначените от лекаря изследвания и лекарствена терапия. Едновременно с това е необходимо определена информация за пациента да се регистрира, да се изпраща, както и да се съхранява. Целта на настоящото проучване е да се установи готовността и уменията на медииинските сестри за въвеждане на информачионни системи в сферата на здравните грижи. Проведено е анкетно проучване на 100 медицински сестри от Университетска болница „Лозенеи” през 2017 г. Получените данни показват, че 1/5 от медииинските сестри в болнииата не могат да работят с компютър и само $12 \%$ са тези, които работят с информационната система на болницата. В същото време близо 90\% от анкетираните посочват, че въвеждат информацията за пациента в тетрадки на ръка, като за тези дейности отделят повече от 1 час от работното си време.

Su $\boldsymbol{m} \boldsymbol{m}$ ary. Establishment of an organization of health care in hospital structures to meet current requirements is impossible without the introduction of information systems in the work of the nursing staff. Basic professional nursing activities are focused on patient care and conducting research directed by doctors and drug therapy, but at the same time it is necessary recording the patient information. The aim of this study is to determine the skills of nurses for the implementation of information systems in health care. Conducted a survey of 100 nurses from the University Hospital "Lozenets" in 2017. Results. The data obtained show that the 1/5 of the nursing staff may not work with a computer, and only $12 \%$ are those who work with the information system of the hospital. Nearly $90 \%$ of respondents indicated that bring patient information in notebooks on hand for these activities spend more than 1 hour of their time.

Key words: information systems, nursing staff, hospital

\section{Въведение}

Създаването на организация на здравните грижи в болничните структури, която да отговаря на съвременните изисквания е невъзможно без въвеждането на информационни системи в работата на сестринския персонал. Основните професионални дейности на медицинските сестри са насочени към грижите за пациента и извършване на назначените от лекаря изследвания и лекарствена терапия, но едновременно с това е необходимо определена информация за пациента да се регистрира, да се изпраща, както и да се съхранява.

Целта на настоящото проучване е да се установи готовността и уменията на медицинските сестри за въвеждане на информационни системи в сферата на здравните грижи.

\section{Материал и методи}

Проведено е анкетно проучване на 100 медицински сестри от Университетска болница „Лозенец” - София, която е база за обучение на студентите от специалност „медицинска сестра” при Медицинския факултет на СУ „Кл. Охридски”, София. Проучването е проведено през месец април на 2013 година, като са включени медицински сестри от всички клиники и отделения на болницата.

\section{Резултати и обсъжАане}

Изучаването на възможностите и условията, свързани с въвеждането на информационните технологии в сферата на здравните грижи, разкрива основни проблеми, които трябва да бъдат разрешавани за да се осигури тяхното ефективно използване.

Значителна част от медицинските сестри в болницата посочват, че притежават определена компютърна грамотност. Близо 1/5 от анкетираните обаче нямат такива умения. Това са по-възрастните медицински сестри, докато всички в млада
Фигура 1. Умения на медицинските сестри за работа с компютьр

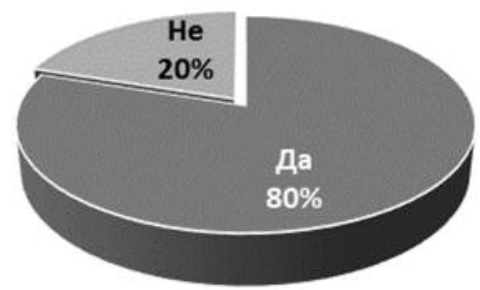

възраст вече израстват с компютъра, като част от тяхното ежедневие. Въвеждането на компютъра като част от сестринската практика ще доведе до затруднения именно на тази част от сестринския персонал, които нямат изградени навици и умения.

Таблица 1. Умения на медииинските сестри за ползване на компютьрни програми и информационни продукти

\begin{tabular}{|lc|}
\hline \multicolumn{1}{|c|}{ Отговори } & $\begin{array}{c}\text { Относителен дял } \\
\text { (\%) }\end{array}$ \\
\hline Word & 52 \\
\hline Exel & 30 \\
\hline Болнична информационна система & 12 \\
\hline Интернет & 80 \\
\hline Други & 5 \\
\hline
\end{tabular}

От представените в таблицата резултати става ясно, че по-голямата част от медицинските сестри ползват основно услугите на интернет. Само половината от умеещите да работят с компютър използват текстова програма на Word, a около $1 / 3$ са тези, които използват електронните таблици на Excel. Една много малка част - $12 \%$ от анкетираните работят 
с болничната информационна система. Обслужването на пациентите в съвременните болници е невъзможно да бъде осъществявано, без да се използват възможностите на информационните технологии, тъй като информацията за пациентите трябва да бъде своевременно регистрирана, съхранявана и разпределяна от различните ползватели при здравноосигурителната система, която функционира в страната. Има известна част от анкетираните, които посочват, че ползват и други информационни продукти.

Тези данни показват, че сред сестринския персонал има известна част, които използват съвременните информационни продукти, но има и не малка част, които никога досега не са работили с компютър и информационни системи.

Таблица 2. Начини за съхраняване на информацията, свързана със сестринските грижи

\begin{tabular}{|lc|}
\hline \multicolumn{1}{|c|}{ Отговори } & $\begin{array}{c}\text { Относите- } \\
\text { лен дял (\%) }\end{array}$ \\
\hline Специализирани компютърни програми & 12 \\
\hline Ръчно писане в тетрадки & 88 \\
\hline Известна част от информацията се предава писмено & 0 \\
\hline Известна част от информацията се предава устно & 0 \\
\hline
\end{tabular}

Получените резултати посочват, че обмена на информация в сферата на грижите все още се осьществява чрез писане на ръка в различни тетрадки - близо 90\% от анкетираните посочват този отговор. Само $12 \%$ са медицинските сестри, които използват специализирани софтуерни продукти при осъществяване на болничните грижи за пациентите. Това са тревожни данни, поради факта, че в болниците през последните години се инвестират значителни ресурси за ремонтни дейности и за медицинска апаратура и техника, а информационното осигуряване на грижите не отговаря на съвременното развитие на информационните технологии.

Фигура 2. Допускане на грешки поради липса на информаичиона система с информация за грижсте

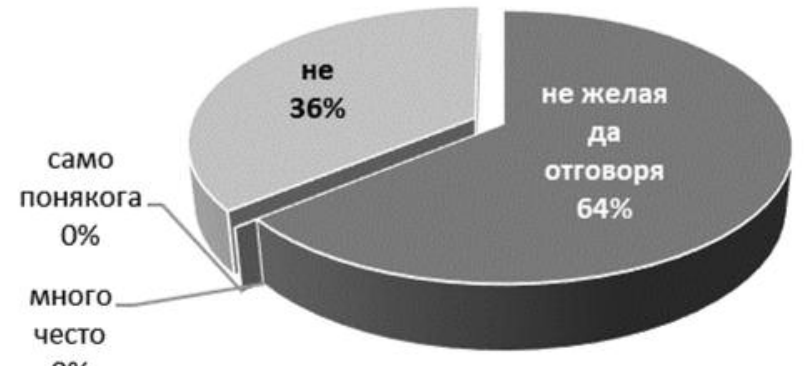

$0 \%$

По интересен начин могат да бъдат тълкувани отговорите на медицинските сестри по въпроса за допускането на грешки поради липса на информационна система в сферата на грижите. Отрицателен отговор са посочили 1/3 от анкетираните, но повече от половината анкетирани не са пожелали да посочат определен отговор.

Тези данни показват, че грешки не липсват в сестринската практика, но липсата на информационна система не позволява доказване и регистриране на грешките. Голяма част от информацията относно грижите за пациентите не се регистрира, а това води до по-голямо натоварване на медицинските сестри, както и до невъзможност да се определи тяхната професионална отговорност. Значителна промяна в организацията на болничните грижи може да бъде осъществена в посока към по-голяма ефективност, ако бъде въведена специализирана информационна система, допълваща общоболничната.
Фигура 3. Намаляване на ангажираността на медиџинските сестри при въвеждане на информационна система

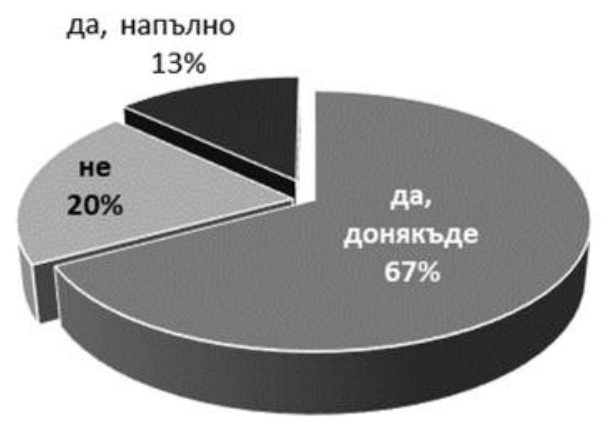

Медицинските сестри смятат, че само донякъде ще бъде намалена тяхната ангажираност след въвеждане на информационната система. Това е така, поради факта, че найголямо трябва да бъде натоварването с грижите към пациента, а информационното осигуряване е необходимо да облекчава работата по документацията и обмена на информация.

Таблица 3. Възможности на медицинските сестри за справяне с информационни системи

\begin{tabular}{|lc|}
\hline \multicolumn{1}{|c}{ Отговори } & $\begin{array}{c}\text { Oтносите- } \\
\text { лен дял (\%) }\end{array}$ \\
\hline Много бързо & 26 \\
\hline Необходим е по-продължителен период & 54 \\
\hline Нямам желание за работа с информационна система & 0 \\
\hline Не желая да отговоря & 20 \\
\hline
\end{tabular}

Представените в таблицата данни показват, че близо $1 / 4$ от медицинските сестри имат възможности да се справят много бързо, ако бъде въведена информационна система в сферата на грижите. За половината от анкетираните е необходим по-продължителен период, който ще е необходим за обучение и адаптация към новата организация. В положителна насока можем да тълкуваме факта, че няма анкетирани, които да посочват, че нямат желание да работят с информационна система. Това показва, че медицинските сестри все по-ясно осъзнават потребностите от съвременно информационно осигуряване на професионалните сестрински грижи в болничните структури. Тези промени от своя страна ще доведат до сериозни промени в организацията на грижите, но това е крайно необходимо, тъй като бяха извършени редица промени в сферата на здравеопазването като цяло, а промяна в същността на организацията на грижите не е осъществявана.

Отговор не са посочили $1 / 5$ от анкетираните и това недвусмислено показва, че е необходимо да се провежда обучение и подготовка на медицинските сестри за промяна на тяхната нагласа и отношение към използването на компютърни и информационни системи.

Таблица 4. Необходимото време за попълване на документация без компютьр

Времето, което отделят медицинските сестри за регистриране и съхраняване на информацията без използването на компютър и инфор-

\begin{tabular}{|lc|}
\hline \multicolumn{1}{|c}{ Отговори } & $\begin{array}{c}\text { Относите- } \\
\text { лен дял (\%) }\end{array}$ \\
\hline До 5 минути & 0 \\
\hline До 15 минути & 12 \\
\hline До 1 час & 0 \\
\hline Повече от 1 час & 88 \\
\hline
\end{tabular}

мационна система е повече от 1 час по време на дежурство. Тези данни доказват изключителната необходимост от въвеждането в сестринската практика на съвременните информационни системи за да бъде рационално използвано работното време с грижи за пациента. 


\section{Изводи}

Въвеждането на информационни системи в сферата на грижите е от особено значение и необходимост, но проблемите ще възникнат поради факта, че около 1/5 от медицинските сестри в болничните структури не могат да работят с компютьр, само $12 \%$ са тези, които работят с информационната система на болницата. Негативен елемент от организацията на болничните грижи е фактът, че почти всички медицински сестри (около 90\%) извършват обмена на информация за пациента в тетрадки на ръка, като за тези дейности отделят повече от 1 час от работното си време.

Определено е необходимо въвеждането на информационни системи в сферата на здравните грижи за обработка на информацията за пациента, но в същото време на медицинските сестри е необходима специална подготовка, както и определен период за адаптация към новата организация на грижите.

\section{Библиография}

1. Балканска, П., Л. Томов, Здравните и социалните грижи - приоритетни насоки в международната стратегия за действие по политиката за възрастните - 2002, Здравен мениджмънт, С., 2003, 3, с. 34-38.

2. Борисов, В., Здравният мениджмънт като функция, В: Здравен мениджмънт, т.I, С., Филвест, 2004c. 135-260.

3. Воденичаров, Ц., Болнично обслужване, В: Социална медицина, Учебник за медицинските колежи, В. Борисов, Ц. Воденичаров, К Юрукова, С. Попова, Акар ПИНТ, София, 2004, 108-112.

4. Воденичаров, Ц., С. Попова, Медицинска етика, С., 2003, с. 230.

5. Воденичаров, Ц., С. Попова, Оценяването в медицинското образование, С., Филвест, 2000, с. 36.

6. Попова, С., Комуникация в сестринството - бариери за ефективна комуникация. Комуникационни умения и автономни функции на сестринството, Пловдив, 2001, с. 63-68.

7. Попова, С., Развитие на сестринството - приоритетни въпроси. Комуникационни умения и автономни функции на сестринството, Пловдив, 2001, с. 7-12.

8. Попова, С., Формиране на умения на пациента за справяне с психосоциални проблеми. Обществено здраве, Ръководство за специализация на медицински сестри, ГорексПрес, С., 2001, с. 133-137.

\footnotetext{
Автор
Доц. Диана Иванова, дм, Медицински фракултет, СУ „Св. Климент Охридски”, тел: +359 884907341, е-таil: dkg@mail.bg
}

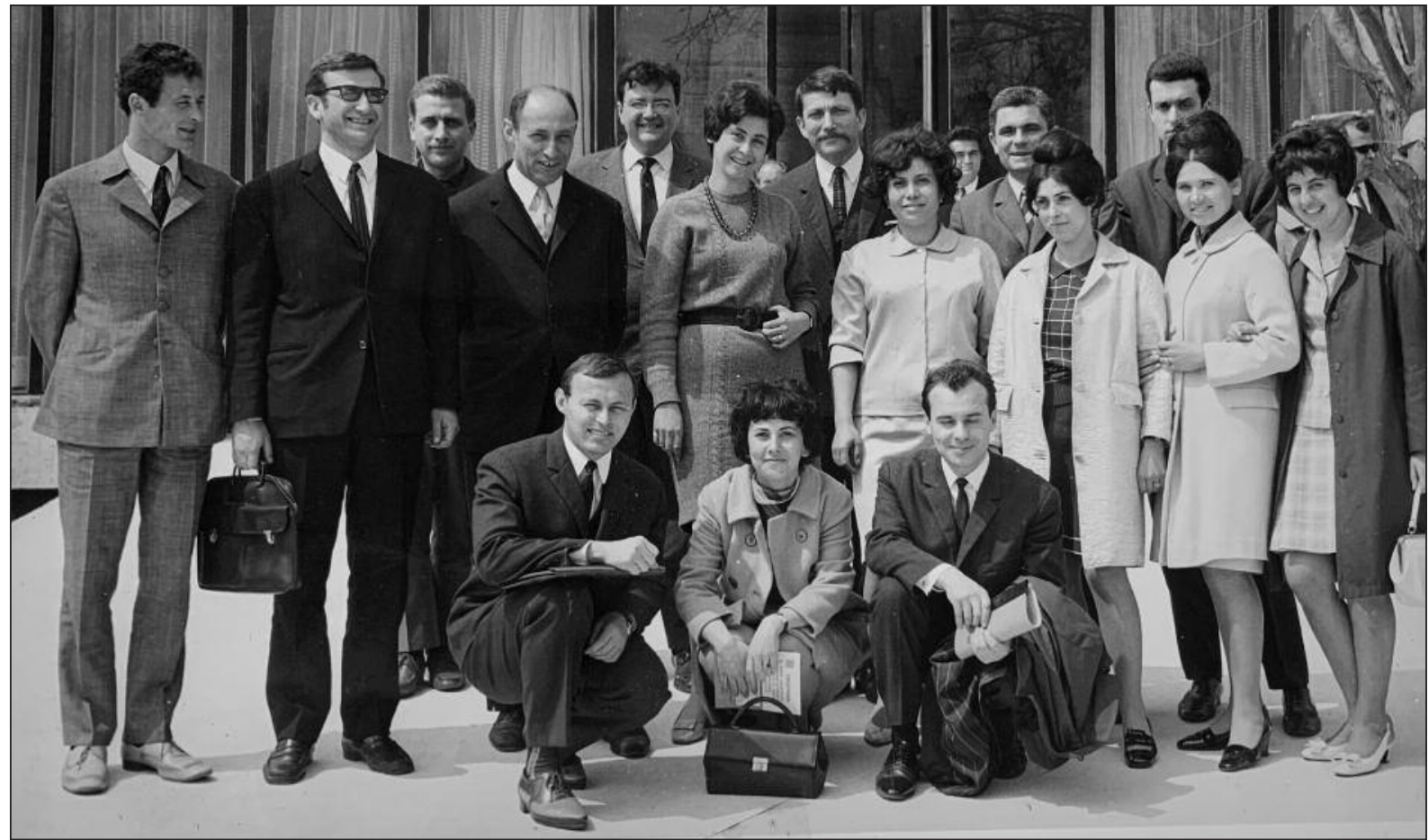

Горе от ляво: 2. Теодор Попов, по-късно професор токсиколог; 4. Владимир Каладжиев, зам.-министър; 5. Ананстас Джеджев, професор по трудова медицина; 5. Мария Ташева; 7. Иван Капинчев; 8. Александра Вълова; 9. Богдан Петрунов, по-късно академик, имунолог; Димитър Цветков - по-късно професор хигиенист. Не са разпознати №№ 1, 10, 12, 13, 14 лекари от мрежата на ХЕИ в страната.

Долу от ляво: 14. Денчо Цоневски, професор хигиенист; 15. П. Чернева; 16. Петър Георгиев, професор епидемиолог.

1969 г. Това е времето, когато набира скорост първият опит за реформа на социалистическото здравеопазване у нас-пре- устройството на хигиенно епидемиологичната мрежа. На кадровото осигуряване в ХЕИ се дава приоритет. С подкрепата на д-р Владимир Калайджиев се изпращат 150 степендианти на хигиенно обучение в Москва, Ленинград и Киев. В ХЕИ се привличат химици, физици, статистици, биолози и инженери. Подкрепя се научноизследователската дейност сред младите специалисти. Снимката е от Първата конференция на младите специалисти от Хигиенно епидемиологичните инспекции, проведена в гр. Варна през м. април. Започва ежегодното им провеждане.

„CM“ 